\title{
The chemical composition and nutritive value of low-alkaloid varieties of white lupin 2. Oligosaccharides, phytates, fatty acids and biological value of protein*
}

\author{
Z. Zduńczyk', J. Juśkiewicz', Marianna Flis ${ }^{2}$, and S. Frejnagel' \\ 'Institute of Animal Reproduction and Food Research, Polish Academy of Sciences, \\ Division of Food Science \\ Tuwima 10,10-718 Olsztyn. Poland \\ 'Institute of Animal Nutrition and Feed Management, \\ Olsziyn Academy of Agriculture and Technology \\ Oczapowskiego 5, 10-718 Olsztyn, Poland
}

(Received 24 August 1995; accepted 12 January 1996)

\begin{abstract}
The oligosaccharide content, fatty acid and amino acid compositions, protein digestibility and growth efficiency were determined in three low-alkaloid varietics of white lupin from the 1993 and 1994 harvest (Wat and Hetman) and the 1992 and 1993 harvest (Bardo). The $x$-galactoside content was relatively low (7.1-8.6\% DM). Phytates constituted 0.7 to $0.9 \%$ of Wat and Bardo seeds, and from 1.2 to $1.6 \%$ of Hetman seeds. Saturated fally acids comprised $13-18 \%$ of total fatty acids, monounsaturated fatty acids $51-57 \%$, and polyunsaturated fatty acids, $27-35 \%$. The lysine content was relatively low $(4.70-5.25 \mathrm{~g} / 16 \mathrm{~g} \mathrm{~N})$, while the limiting amino acid was methionine. The chemical score (CS) calculated for methionine and cystine ranged from 35 to $45 \%$ as related to cgg protein and 35 to $41 \%$ in relation to the ideal protein for pigs. The true digestibility coefficient (TD, 83-86\%) and the protein efficiency ratio (PER) for seeds supplemented with methionine (1.99-2.19) did not differ significantly. The obtained results do not, however, point to intervarietal differences in oligosaccharide content and protein and fat quality. However, significant variability in the characteristics was found, depending on the year of harvest.
\end{abstract}

KEY WORDS: white lupin, oligosaccharides, phytates, fatty acids, amino acids, digestibility, PER

* The study was supported by the State Committee for Scientific Research, Project 5 S30503507 


\section{INTRODUCTION}

The practice of Polish plant breeding stations has shown that it is possible to obtain more than $1000 \mathrm{~kg}$ protein per hectare from white lupin, i.e. significantly more than from other lupin species (Pagowska, 1990).

The white lupin seeds contain $34-38 \%$ crude protein in DM (Buraczewska et al., 1993; Eggum et al., 1993; Alloui et al., 1994; Smulikowska et al., 1995; Zdunczyk et al., 1996) that is characterized by a low methionine, tryptophane and lysine contents (Prieto and Aguilera, 1986; Batterham, 1989; Donovan et al., 1991). After supplementation with these amino acids, lupin seeds can be a good source of protein in the diet of monogastric animals, under the condition that the alkaloid level in the seeds is sufficiently low and does not limit feed intake or utilization. During the early 1980 s, white lupin varieties and lines contained from 0.4 to $1.7 \mathrm{mg} / \mathrm{g}$ total alkaloids (Wiatr, 1989). Hetman, a new variety registered later and Bardo, the newest variety, contain less alkaloids (under $1 \mathrm{mg} / \mathrm{g}$ ) (Buraczewska et al., 1993; Alloui et al., 1994; Zduńczyk et al., 1996), and due to that the seeds of these varieties can be more widely used in the nutrition of monogastric animals. The small number of nutritional studies performed do not provide a full assessment of the chemical composition and nutritional value of the new varieties. This applies in particular to the oligosaccharide and phytate contents, as well as to protein and fat. According to many authors the oligosaccharide fraction should be classified as a lupin antinutrient (Eskin et al., 1980; Saini, 1989).

In this study we determined the $\alpha$-galactoside and phytate contents, total fatty acid and amino acid compositions, protein digestibility and protein efficiency ratio (PER) of Polish low-alkaloid varieties of white lupin in order to better assess the nutritional value of this crop.

\section{MATLRIAL AND METHODS}

White lupin seeds were obtained from Polish seed stations (Kosieczyn, Przebeedowo and Wiatrowo) situated the western and south-western regions of Poland. Seeds of the Wat and Hetman varieties were from successive harvests in 1992 and 1993, while Bardo variety seeds from 1992 and 1994. The differences in size, weight, proportion of seed coat and chemical composition of the seeds, cotyledons and sced coat were described in the first part of this study (Zdunczyk et al., 1996).

Total protein and crude fat contents after acid hydrolysis were determined by standard methods (AOAC, 1990), sucrose and $\alpha$-galactosides (raffinose, stachyose and verbascose) contents were determined by HPLC in samples prepared 
according to Múzquiz (1992). Phytates separated into individual inositol phosphates (from tri- to hexaphosphates) were determined by HPLC after sample preparation according to Sandberg and Ahderinne (1986). The total fatty acid composition was determined using a Shimadzu GC-14A gas chromatograph.

The amino acid composition was determined using an automatic Beckman Model 6300 analyzer after hydrolyzing the samples in $6 \mathrm{~N} \mathrm{HCl}$. Sulphur-containing amino acids were determined after oxidizing the samples with formic acid, while tryptophane after hydrolysis with barium hydroxide. Protein quality was determined using the essential amino acid index according to Oser (EAAI), with egg protein composition as the standard. An additional index was calculated $\left(\mathrm{EAAI}_{\mathrm{nig}}\right.$ ), in which the standard was the ideal protein for pigs developed by Wang and Fuller (1990).

The protein efficiency ratio (PER) was determined using Wistar rats aged 27-30 days and weighing $65.9 \pm 3.4 \mathrm{~g}$ at the start of the test. The experimental groups were composed of 8 rats of both sexes at a $1: 1$ ratio. The diets contained $10 \%$ crude protein derived from the seeds of the lupin varieties under study. The diets were supplemented with DL-methionine $(0.25 \%)$, soyabean oil $(7.5 \%)$ and the standard amount of a mineral mixture (according to NRC, 1976) and vitamin mixture (according to AOAC, 1975). The digestibility of crude protein was determined on the same rats in the last weck of the growth test. The true protein digestibility coefficient was calculated by subtracting the amount of metabolic nitrogen, estimated according to Rakowska (1978).

The preferences of rats for the experimental diets were additionally determined using seeds from the 1994 harvest. The experiment was carried out according to Dayton and Morril (1974) on 15 males weighing $90.0 \pm 3.5 \mathrm{~g}$. Each rat was allowed free access to 3 containers with different diets. The consumption of each diet was measured daily, the order in which the containers were placed was changed.

The results were subjected to statistical analysis, using the Duncan test.

\section{RESULTS AND DISCUSSION}

The seeds of the analysed varieties contained from 1.7 to $3.3 \%$ sucrose and from 7.1 to $8.6 \% \alpha$-galactosides, i.e. raffinose, stachyose and verbascose in DM (Table 1). Eskin et al. (1980) and Cuadra et al. (1994) found similar amounts of the oligosaccharide fraction $(7.4 \% \mathrm{DM})$. Comparing our results with the data from many studies compiled by Saini (1989), it can be seen that the seeds of Polish white lupin varieties have a low $\alpha$-galactoside content. According to the data reported by Saini (1989), white lupin seeds contain from 7 to $14 \% \alpha$-galactosides, 
TABLE 1

Content of saccharose and $x$-galactosides in sceds, $\%$ DM

\begin{tabular}{|c|c|c|c|c|c|c|}
\hline \multirow{3}{*}{ Ingredient } & \multicolumn{6}{|c|}{ Cultivar, year of harvest } \\
\hline & \multicolumn{2}{|c|}{ Wat } & \multicolumn{2}{|c|}{ Hetman } & \multicolumn{2}{|c|}{ Bardo } \\
\hline & 1993 & 1994 & 1993 & 1994 & 1992 & 1994 \\
\hline Saccharose & 2.94 & 3.04 & 1.67 & 2.83 & 3.07 & 3.30 \\
\hline Raffinose & 0.68 & 0.62 & 0.75 & 0.92 & 0.59 & 0.83 \\
\hline Stachyose & 6.25 & 6.53 & 7.34 & 6.09 & 6.87 & 6.65 \\
\hline Verbascose & 0.38 & 0.68 & 0.48 & 0.79 & 0.34 & 0.56 \\
\hline Total $\alpha$-galactosides & 7.31 & 7.83 & 8.57 & 7.08 & 7.69 & 8.04 \\
\hline
\end{tabular}

while in the seeds of other lupin species, then can reach even $20 \%$. Our results do not, however, let us draw conclusions about differences between varieties in respect to the studied compounds. They do, however, show that different conditions of vegetation and harvest in different years can affect the oligosaccharide content in the seeds of the same variety.

The inositol hexaphosphate level, which is the main phytate fraction in the seeds of the studied varieties, was rather high and variable (Table 2). Total inositol phosphates ranged from 7 to $16 \mathrm{~g} / \mathrm{kg}$ and was higher than values found by Burbano et al. (1995) and Caudra et al. (1994) in high alkaloid white lupin seeds. In the case of Wat and Bardo, total inositol phosphates contents $(7-9 \mathrm{~g} / \mathrm{kg})$ were similar to values reported by Elkowicz and Sosulski (1982) and Caudra et al. (1992). The seeds of the Hetman variety were found to have a surprisingly high inositol phosphate content (16.2 and $12.2 \mathrm{~g} / \mathrm{kg}$ ). The elevated phytate content, especially IP-5 and IP-6 that form stable complexes with many elements can limit the availability of both phosphorus, as well as $\mathrm{Ca}, \mathrm{Mg}, \mathrm{Zn}$ and $\mathrm{Cu}$ (Fox and Tao, 1989).

TABLE 2

Content of particular and total of inositol phosphates (IP) in seeds

\begin{tabular}{|c|c|c|c|c|c|c|}
\hline \multirow{3}{*}{ Ingredient } & \multicolumn{6}{|c|}{ Cultivar, year of harvest } \\
\hline & \multicolumn{2}{|c|}{ Wal } & \multicolumn{2}{|c|}{ Hetman } & \multicolumn{2}{|c|}{ Bardo } \\
\hline & 1993 & 1994 & 1993 & 1994 & 1992 & 1994 \\
\hline $\mathrm{IP}-3, \mu \mathrm{mol} / \mathrm{g}$ & - & - & - & - & - & - \\
\hline $\mathrm{IP}-4, \mu \mathrm{mol} / \mathrm{g}$ & 0.03 & 0.02 & 0.15 & 0.04 & 0.03 & 0.01 \\
\hline IP-5, $\mu \mathrm{mol} / \mathrm{g}$ & 0.40 & 0.23 & 0.71 & 0.23 & 0.29 & 0.13 \\
\hline $\mathrm{IP}-6, \mu \mathrm{mol} / \mathrm{g}$ & 13.52 & 13.70 & 23.64 & 18.28 & 10.33 & 10.48 \\
\hline Total IP, $\mu \mathrm{mol} / \mathrm{g}$ & 13.95 & 13.95 & 24.50 & 18.55 & 10.65 & 10.62 \\
\hline Total IP, g/g & 9.21 & 9.21 & 16.17 & 12.24 & 7.03 & 7.01 \\
\hline
\end{tabular}


TABLE 3

Fatty acid composition of the fatty extract from lupin seeds, $\%$ of mcthyl csters

\begin{tabular}{|c|c|c|c|c|c|c|}
\hline \multirow{3}{*}{ Specification } & \multicolumn{6}{|c|}{ Cultivar, year of harvest } \\
\hline & \multicolumn{2}{|c|}{ Wat } & \multicolumn{2}{|c|}{ Hetman } & \multicolumn{2}{|c|}{ Bardo } \\
\hline & 1993 & 1994 & 1993 & 1994 & 1992 & 1994 \\
\hline Ether cxtract, \% DM & 9.67 & 9.53 & 11.01 & 8.87 & 10.61 & 10.17 \\
\hline $\begin{array}{l}\text { Saturated fatty acids: } \\
\text { - palmitic acid, } C_{16: 0} \\
\text { - stearic acid, } C_{18: 0} \\
\text { - eicosenoic acid, } C_{20: 0} \\
\text { - behenic acid, } C_{22: 0} \\
\text { - total }\end{array}$ & $\begin{array}{r}8.07 \\
1.34 \\
0.66 \\
3.76 \\
13.83\end{array}$ & $\begin{array}{r}10.83 \\
1.56 \\
0.82 \\
4.47 \\
17.68\end{array}$ & $\begin{array}{r}7.23 \\
1.47 \\
0.75 \\
3.09 \\
12.54\end{array}$ & $\begin{array}{r}11.30 \\
1.91 \\
0.84 \\
3.85 \\
17.90\end{array}$ & $\begin{array}{r}8.50 \\
1.68 \\
0.78 \\
3.51 \\
14.47\end{array}$ & $\begin{array}{r}9.41 \\
1.70 \\
0.85 \\
4.92 \\
16.88\end{array}$ \\
\hline $\begin{array}{l}\text { Mononusatutrated fatty acids: } \\
\text { - palmitoleic acid, } \mathrm{C}_{16: 1} \\
\text { - olcic acid, } \mathrm{C}_{18: 1} \\
\text { - erucic acid, } \mathrm{C}_{22: 1} \\
\text { - total }\end{array}$ & $\begin{array}{r}0.51 \\
48.77 \\
1.76 \\
51.04\end{array}$ & $\begin{array}{r}0.91 \\
51.79 \\
1.95 \\
54.65\end{array}$ & $\begin{array}{r}0.32 \\
53.11 \\
1.38 \\
54.81\end{array}$ & $\begin{array}{r}0.88 \\
52.40 \\
2.13 \\
55.41\end{array}$ & $\begin{array}{r}0.51 \\
54.79 \\
2.13 \\
57.43\end{array}$ & $\begin{array}{r}0.91 \\
51.07 \\
2.74 \\
54.72\end{array}$ \\
\hline $\begin{array}{l}\text { Polyunsaturatcd fatty acid: } \\
\text { - linoleic acid, } \mathrm{C}_{18: 2} \\
\text { - eicosenoic acid, } \mathrm{C}_{20: 2} \\
\text { - linolenic acid, } \mathrm{C}_{18: 3} \\
\text { - total }\end{array}$ & $\begin{array}{r}21.83 \\
0.35 \\
12.95 \\
35.13\end{array}$ & $\begin{array}{r}15.54 \\
0.23 \\
11.90 \\
27.67\end{array}$ & $\begin{array}{r}19.63 \\
0.25 \\
12.77 \\
32.65\end{array}$ & $\begin{array}{r}14.78 \\
0.23 \\
11.68 \\
26.69\end{array}$ & $\begin{array}{r}15.46 \\
0.25 \\
12.18 \\
27.89\end{array}$ & $\begin{array}{r}16.93 \\
0.32 \\
11.46 \\
28.71\end{array}$ \\
\hline $\begin{array}{l}\text { Ratio-saturated fatty acid ( } 1.0) \text { : } \\
\text { - monounsaturated fatty acid } \\
\text { - polyunsaturated fatty acid }\end{array}$ & $\begin{array}{l}3.7 \\
2.5\end{array}$ & $\begin{array}{l}3.1 \\
1.6\end{array}$ & $\begin{array}{l}4.4 \\
2.6\end{array}$ & $\begin{array}{l}3.1 \\
1.5\end{array}$ & $\begin{array}{l}4.0 \\
1.9\end{array}$ & $\begin{array}{l}3.2 \\
1.7\end{array}$ \\
\hline
\end{tabular}

The crude fat content in seed dry matter of the lupin varictics equaled about $10 \%$ (Table 3 ). In all, saturated fatty acids constituted about 12.5 to $17.9 \%$, the proportion of monounsaturated fatty acids exceeded $50 \%$, while polyunsaturated fatty acids accounted for 26.7 to $35.1 \%$ of the total. In comparison with the data of other authors (Mason et al., 1990; Singh et al., 1995), the proportion of saturated fatty acids in our study was higher (by 3-7 percentage units), while the proportion of monounsaturated fatty acids was lower, especially in seeds from 1994. In the white lupin seed oil analyzed by Mason et al.(1990), the proportions of the assayed fractions were, respectively, 10,60 and $30 \%$.

The amino acid composition of seed protein is given in Table 4. The lysine content varied from 4.70 to $5.25 \mathrm{~g} / 16 \mathrm{~g} \mathrm{~N}$ and was in the range reported by others (Brenes et al., 1993; Eggum et al., 1993; Buraczewska et al., 1994). However, in many studies (Batterham et al, 1986; Yanez, 1990; Eggum et al., 1993), the lysine content was lower $(3.7-4.6 \mathrm{~g} / 16 \mathrm{~g} \mathrm{~N})$. The differences in the lysine content in the same variety, but in different years (Hetman, 4.70 and $5.00 \mathrm{~g} / 16 \mathrm{~g} \mathrm{~N}$ and Bardo, 
TABLF, 4

Crude protein content in seeds and amino acid composition of protein

\begin{tabular}{|c|c|c|c|c|c|c|}
\hline \multirow{3}{*}{ Specification } & \multicolumn{6}{|c|}{ Cultivar, year of harvest } \\
\hline & \multicolumn{2}{|c|}{ Wat } & \multicolumn{2}{|c|}{ Hetman } & \multicolumn{2}{|c|}{ Bardo } \\
\hline & 1993 & 1994 & 1993 & 1994 & 1992 & 1994 \\
\hline $\begin{array}{l}\text { Crude protein, \% DM } \\
\text { Amino acid }(\mathrm{g} / 16 \mathrm{~g} \mathrm{~N})\end{array}$ & 35.77 & 34.30 & 36.22 & 38.16 & 37.90 & 38.07 \\
\hline $\mathrm{His}$ & 2.86 & 3.12 & 2.89 & 3.18 & 2.80 & 3.17 \\
\hline Lys & 4.93 & 4.94 & 4.70 & 5.00 & 5.25 & 4.80 \\
\hline Phe + Tyr & 8.90 & 8.93 & 7.83 & 8.53 & 8.43 & 8.63 \\
\hline Met & 0.86 & 0.80 & 0.81 & 0.74 & 0.82 & 0.78 \\
\hline Cys & 1.55 & 1.79 & 1.55 & 1.78 & 1.42 & 1.74 \\
\hline Thr & 3.81 & 3.35 & 3.49 & 3.33 & 3.77 & 3.24 \\
\hline Trp & 0.84 & 0.83 & 0.83 & 0.85 & 0.88 & 0.86 \\
\hline Ile & 4.65 & 4.33 & 4.38 & 4.10 & 4.58 & 4.18 \\
\hline Leu & 7.84 & 7.62 & 7.76 & 7.54 & 7.90 & 7.36 \\
\hline Val & 4.60 & 4.02 & 4.20 & 3.90 & 4.69 & 4.11 \\
\hline $\mathrm{CS}^{1}$ & 37.7 & 43.8 & 36.9 & 44.8 & 35.0 & 44.1 \\
\hline EAAI & 69.0 & 67.4 & 65.6 & 66.7 & 68.9 & 66.6 \\
\hline $\mathrm{CS}_{\text {nig }}^{2}$ & 41.0 & 38.1 & 38.6 & 35.2 & 39.0 & 37.1 \\
\hline EAAI $_{\text {pig }}$ & 83.0 & 81.0 & 80.6 & 80.7 & 82.9 & 80.0 \\
\hline
\end{tabular}

'methionine with cystine

${ }^{2}$ methionine with cystine (methionine $55 \%$ sum S-AA)

5.25 and $4.80 \mathrm{~g} / 16 \mathrm{~g} \mathrm{~N}$ ) are difficult to explain. It is not possible, however, to conclude that there are differences in the amino acid composition between the studied varieties. All of the studied seeds had the low content of sulphur amino acids characteristic for white lupin, and higher content of cystine than methionine. Because of the low methionine content $(0.74-0.86 \mathrm{~g} / 16 \mathrm{~g} \mathrm{~N})$, the value of the lupin protein is limited by sulphur-containing amino acids, regardless if the sum of both amino acids was compared with egg protein, or with the ,ideal" protein for pigs (Table 4). In comparison with the ,ideal" protein for pigs (Wang and Fuller, 1990), the essential amino acid index $\left(\mathrm{EAAI}_{\text {pig }}\right)$ was high and exceeded 80 in all samples.

No significant differences were found in digestibility and PER of the seed protein among the varieties (Table 5). The true digestibility coefficients of protein were within the range of $83-86 \%$ which is in agreement with the results of Eggum et al. (1993). The PER ranged from 1.99 to 2.19. Only by differences in the value of the limiting amino acid index can the higher PER values of 1994 seeds be explained, including the differences in the PER of Bardo seed protein (1.99 and 2.16). This may be an indication that the methionine supplement was insufficient and sulphur-containing amino acids limited the biological value of protein in the experimental diets. 
TABLE 5

Protein digestibility (TD) and protein efficiency ratio (PER)

\begin{tabular}{lcc}
\hline Cultivar, year of harvest & TD & PER \\
\hline Wat & & \\
1993 & $83.5 \pm 0.56$ & $2.15 \pm 0.12$ \\
1994 & $85.1 \pm 1.99$ & $2.19 \pm 0.25$ \\
Hetman & & \\
1993 & $82.8 \pm 1.10$ & $2.10 \pm 0.11$ \\
1994 & $86.1 \pm 3.16$ & $2.19 \pm 0.21$ \\
Bardo & & \\
1992 & $83.6 \pm 0.92$ & $1.99 \pm 0.16$ \\
1994 & $85.2 \pm 2.46$ & $2.16 \pm 0.24$ \\
\hline
\end{tabular}

The newer varieties, Hetman and Bardo, were not inferior in terms of PER to the old variety, Wat. The experiments of Wasilewko et al. (1995) also showed that the BV of protein of Bardo did not differ from the BV of Wat seed protein (76.0). The differences in alkaloid and fibre content of the particular varieties discussed in the first part of this study (Zduńczyk et al., 1996), i.e. the higher content of both fractions in Wat seeds, did not affect the results of growth test on rats. In the test on feed preferences, lupin variety was found to have an effect on feed intake if
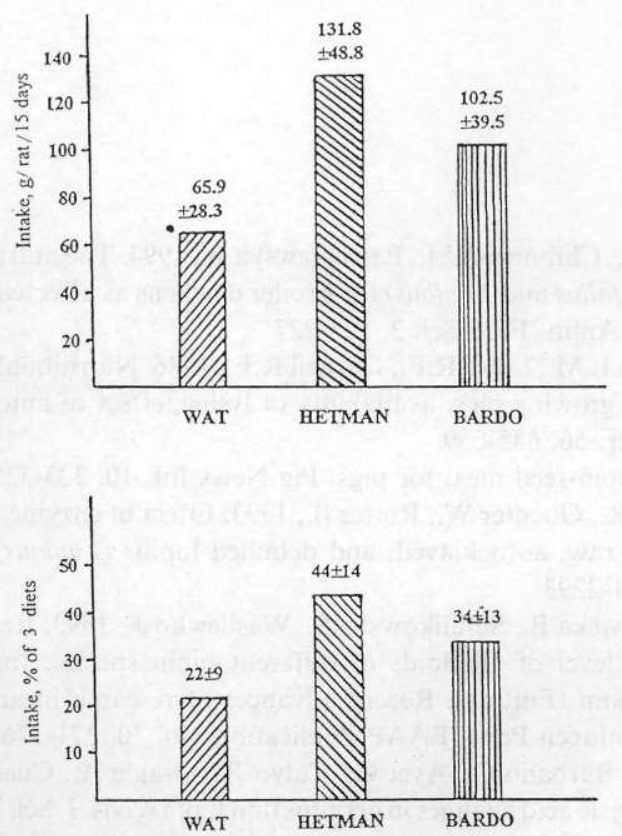

Figure 1. Intake of diets containing seeds of different sweet lupin varieties in a free choice test 
the rats were allowed to freely choose among rations: intake of feeds containing Wat seeds was, on average, half that of Hetman and Bardo varieties (Figure 1). This may have been caused by the lower alkaloid content in these seeds than in Wat seeds (Zduńczyk et al., 1996). This effect was not noted, however, in the standard growth test. The results of comparative experiments show that rats are less sensitive than young pigs to the level of alkaloids in the diet (Buraczewska et al., 1993). The results of our analyses (including that of alkaloid, oligosaccharide and phytate contents) did not explain why rats preferred the diet containing Hetman seeds over that of Bardo.

\section{CONCLUSIONS}

In conclusion the results of the study show that the seeds of the white lupin varieties Wat, Hetman and Bardo have a similar content and composition of oligosaccharide fractions and fat and protein. Hetman seeds contained more phytates. In growth tests on rats, no differences were found in protein digestibility or PER. When rats had free choice of diets, they ate less of the ration containing seeds of the older variety, Wat.

\section{REFERENCES}

Alloui O., Smulikowska S., Chibowska M., Pastuszewska B., 1994. The nutritive value of lupin seeds (L. luteus, $L$. angustifolius and $L$. albus) for broiler chickens as affected by variety and enzyme supplementation. J. Anim. Feed Sci. 3, 215-227

Batterham E.S., Andersen L.M., Lowe R.F., Darncll R.E., 1986. Nutritional value of lupin (Lupinus albus) sced meal for growing pigs: availability of lysine, effect of autoclaving and net energy content. Brit. J. Nutr. 56, 645-659

Batterham E.S., 1989. Lupin-seed meal for pigs. Pig News Inf. 10, 323-325

Brenes A., Marquardt R.R., Guenter W., Rotter B., 1993. Effect of enzyme supplementation on the nutritional valuc of raw, autocklaved, and dehulled lupins (Lupinus albus) in chicken diets Poultry Sci. 72, 2281-2293

Buraczewska L., Pustuszewska B., Smulikowska S., Wasilewko J., 1993. Response of pigs, rats and chickens to dietary level of alkaloids of different lupin species. In: T.F.B. van der Poel, J. Huisman, H.S. Saini (Editors), Recent advances of rescarch in antinutritional factors in legume seeds. Wageningen Pers., EAAP Publication No. 70, 371-376

Caudra C., Múzquiz. M., Burbano C., Ayet G., Calvo R., Osagie A., Cuadro C., 1994. Alkaloid, $\alpha$-galactoside and phytic acid changes in germination lupin seeds. J. Sci. Food Agric. 66, 357-364

Dayton A.D., Morrill J.Z., 1974. A model to estimate the palatability of several calf starter rations. J. Dairy Sci. $57,482-484$ 
Donovan B.C., Mc Niven M.A., Mac Leod J.A., Anderson D.M., 1991. Protein quality of two cultivars of lupin secds cyaluated in weanling rats. Anim. Fecd Sci. Technol. 33, 87-95

Elkowicz. K., Sosulski F.W., 1982. Antinutritive factors in eleven legumes and their air-classified protein and starch fractions. J. Food Sci. 47, 1301-1304

Eggum B.O., Tomes G., Beames R.M., Datta F.U., 1993. Protcin and cnergy cvaluation with rats of sceds from 11 lupin cultivars. Anim. Fecd Sci. Technol. 43, 109-119

Eskin N.A.M., Johanson S., Vaisey-Genser M., McDonald B.E., 1980. A study of oligosaccharides in a selected group of legumes. J. Can. Inst. Food Sci. Technol. 15, 40-42

Fox M.R.S., Tao S.H.. 1989. Antinutritive effect of phytate and other phosphorylated derivatives. Nutr. Toxicol. 3, 59-96

Mason L., Romero N., Mella M., 1990. Fatty acid composition of the fat extracted from different lupin seed varieties. Proceedings $6^{\text {th }}$ International Lupin Conference, Temuco-Pucon (Chile), pp. 16-19

Múzquiz M., Rey C., Cuadrado C., 1994. Effect of germination on oligosaccharide content of lupin species. J. Chromatogr. 607, 349-352

Pągowska E., 1990. Lupinus luteus, L. angustifolius, L. albus. Synthesis results of variety of experiments 1989 (in Polish). COBORU, Stupia Wielka, 901

Pricto C., Aguilera, 1986. The effect of the supplementation with methioninc and lysine of diets based on lupin seed (Iapinus albus var. multolupa) on protein and energy utilization in growing rats. J. Anim. Physiol. Anim. Nutr. 55, 239-246

Rakowska M., Szkilłądziowa W., Kunachowicz H., 1978. Biological value of food protein (in Polish) WNT, Warszawa, pp. 204-205

Saini H.S., 1989. Legume seed oligosaccharides. In: T.F.B. van der Poel, J. Huisman, I.E., Lienr (Editors), Recent Advances of Research in Antinutritional Factors in Legume Seeds. Pudoc Wageningen, pp. 329-341

Sandberg A.S., Ahderinne R., 1986. HPLC method for determination of inositol tri-, tetra-, penta-, and hexaphosphates in foods and intestinal content. J. Food Sci. 51, 547-550

Singh C.K., Robinson P.H., McNiven M.A., 1995. Evaluation of raw and roasted lupin seeds as protein supplements for lactating cows. Anim. Feed Sci. Technol. 52, 63-76

Smulikowska S., Wasilewko J., Mieczkowska A., 1995. A note on the chemical composition of the cotyledons and seed coat of three species of sweet lupin. J. Anim. Feed Sci. 4, 69-76

Wang T.C., Fuller M.F., 1990. The effect of the plane of nutrition on the optimum dielary amino acid pattern for pigs. Anim. Prod. 50, 155-164

Wasilewko J., Pastuszewska B., Ochtabińska A., Buraczewska L., 1995. Amino acid composition and biological value of the proteins of three lupin species. Proceedings of 2nd European Conference on Grain Legumes, Copenhagen, p. 276

Wiatr K., 1984. Lupinus huteus, L. angustifolius, L. albus. Synthesis results of varicty of experiments 1989 (in Polish). COBORU, Słupia Wielka, 724

Yancz E., 1990. Lupin as a source of protein in human nutrition. Proceedings of $6^{\text {th }}$ International Lupin Conference, Temuco-Pucon (Chile), pp. 115-123

Zduńczyk Z., Juśkiewicr. J., Flis M., Amarowicz R., Krefft B., 1996. Chemical composition and nutritive value of low alkaloid seeds of white lupin cultivars. 1. Characteristics of whole seeds cotyledons and hulls. J. Anim. Feed Sci. 5, 63-72 


\section{STRESZCZENIE}

Skład chemiczny $\mathbf{i}$ wartość pokarmowa nasion niskoalkaloidowych odmian lubinu bialego 2. Oligosacharydy, fityniany, kwasy tluszczowe $i$ wartość biologiczna białka

Oznaczono zawartość oligosacharydów, skład kwasów tłuszczowych i aminokwasowy oraz strawność i wydajność wzrostową białka trzech niskoalkaloidowych odmian łubinu białego ze zbiorów 1993 i 1994 r (Wat i Hetman) oraz 1992 i 1993 r (Bardo). Zawartość $\alpha$-galaktozydów była stosunkowo niska (7,1-8,6\% s.m.). Zawartość fitynianów wynosiła $0,7-0,9 \%$ w nasionach odmiany Wat i Bardo, do 1,2-1,6\% wasionach odmiany Hetman. Kwasy nasycone stanowiły $13-18 \%$, jednonienasycone $51-57 \%$ ord\% wielonienasycone $27-35 \%$ sumy kwasów tłuszczowych. Udział lizyny w białku był stosunkowo niski $(4,70-5,25 \mathrm{~g} / 16 \mathrm{~g} \mathrm{~N})$, a aminokwasem ograniczającym wartość białka była metionina. Wskaźnik aminokwasu ograniczającego (CS), obliczony dla metioniny z cystyną, wynosił od 35 do $45 \%$ w stosunku do białka jaja kurzego i 35 do $41 \%$ w stosunku do idealnego białka dla świń. Współczynniki strawności rzeczywistej TD (83-86\%) oraz wskaźniki wydajności wzrostowej białka PER nasion uzupelnionych metioniną $(1,99-2,19)$ nie różniły się istotnie. Uzyskane wyniki nie pozwalają jednak na wskazanie odmianowych różnic w zawartości oligosacharydów oraz jakości białka i tłuszczu. Stwierdzono natomiast dużą zmienność analizowanych cech w zależności od roku zbioru nasion. 